\title{
Wstęp
}

\section{Wyspy pełne głosów}

\section{Agnieszka BąBel}

ORCID: 0000-0002-I82I-9399

(Instytut Badań Literackich PAN, Warszawa)

\author{
Wyspa ta jest petna dźwięków, \\ Gtosów i stodkich piesni, które cieszq, \\ Nie szkodzqc wcale.
}

\author{
William Szekspir, \\ Burza, akt III, scena 2 \\ (tłum. M. Słomczyński)
}

Wyspa jest oczywistym skojarzeniem, które często przywołuje się w kontekście rozważań o ludzkiej egzystencji, współistnieniu z innymi, a wreszcie o kwestiach izolacji i komunikacji oraz ich wpływie na jednostkę i społeczeństwo. Znane angielskie powiedzenie: „Nikt nie jest samotną wyspą” (w oryginale właściwie chodzi o wyspę samodzielną, samoistną, „intire of it selfe”, bo tymi słowy upominał swe pochłonięte pogonią za ziemskimi rozkoszami audytorium poeta i kaznodzieja John Donne w Medytacji XVII $)^{\mathrm{I}}$ wykorzystuje dwuznaczność owej geograficznej, społecznej i duchowej metafory, rozpiętej między zewnętrznym nakazem lub igrasz-

1 Obszerniejszy kontekst tego znanego cytatu w oryginalnej wersji brzmi następująco: „No man is an Island, intire of it selfe; every man is a peece of the Continent, a part of the maine; if a Clod bee washed away by the Sea, Europe is the lesse, as well as if a Promontorie were, as well as if a Mannor of thy friends or of thine own were; any mans death diminishes me, because I am involved in Mankinde; And therefore never send to know for whom the bell tolls; It tolls for thee" (J. Donne, Devotions upon Emergent Occasions, 1623; cyt. za: O. Tearle, A Short Analysis of John Donne's 'No Man Is an Island' Meditation, https://interestingliterature.com/2020/06/john-donne-no-man-is-an-island-for-whom-the-bell-tolls-meditation-analysis/ (stan z 20 grudnia 2021 r.). 
ką przypadku a samodzielnym wyborem. Słowniki symboli przypisują wyspie najrozmaitsze sensy pozytywne i negatywne, począwszy od osamotnienia i śmierci, kończąc na raju, miejscu osiągnięcia doskonałości i duchowego oświecenia: „Wyspa symbolizuje odosobnienie, osobliwość, osamotnienie, ucieczkę od świata, pierwotne centrum duchowe, schronienie przed otaczającym oceanem mierności a. namiętności, a. podświadomości, nadnaturalny świat, Kosmos; porządek, pokój, szczęście, piękno, doskonałość, raj; trwałość, wyższość; utopię; kobiecość; śmierć, Elizjum, miejsce pobytu dusz; wyzwanie dla podróżnika, odkrywcy; Anglię"”. Już w starożytności odwiedzający wyspy mitologiczni bohaterowie przypisywali im najróżniejsze znaczenia - dla Odyseusza obce wyspy to miejsca uwięzienia i przeszkody w swobodnej podróży, Itaka zaś stanowiła upragniony cel, własne królestwo. Wyspy antyku bywają też miejscem zesłania (jak Pandateria), azylem tyrana (Capri), naturalną celą, a zarazem schronieniem wizjonera (Patmos), miniaturowym rajem ziemskich rozkoszy (Cytera)... Owa migotliwa wieloznaczność wyspy jest chętnie wykorzystywana dla zilustrowania złożonych relacji między jednostką a społeczeństwem, kwestii granicy między dobrowolnością decyzji a brutalnym przymusem, zewnętrznością a światem wewnętrznym, potrzebą zachowania własnej integralnej tożsamości a pragnieniem kontaktu $\mathrm{z}$ innymi.

Rozprawy zebrane w najnowszym tomie rocznika „Napis” Izolacja i komunikacja. Rozważania nad formami komunikacji literackiej i kulturowej powstałym jako reakcja na doświadczenia ostatnich lat pandemii, również nierzadko odwołują się do toposu wyspy. Może być ona rozumiana jako konkretne odniesienie geograficzne, a zarazem symbol ograniczenia w relacjach międzyludzkich (na przykład artykuł wprowadzający Jacka Wasilewskiego Izolacja i komunikacja. Rodzaje izolacji i towarzyszace im deficyty komunikacyjne, inspirowany semiotyczną praktyką analityczną notness, czyli analizy opozycji, w które uwikłane jest dane zjawisko). Idylliczny motyw „wyspy miłości”, na pół fantastycznej przestrzeni, w której na chwilę przestają obowiązywać społeczne i obyczajowe normy, stanowi główny wątek tekstu Tomasza Jędrzejewskiego (Rokoko. Izolacja i azyl. O poezji cyteryjskiej „kręgu Marii Wirtemberskiej"). Dobrowolność izolacji, świadomy wybór osamotnienia jako sytuacji umożliwiającej niepowtarzalność przeżycia wspinaczki górskiej jest tematem artykułu Przemysława Kaliszuka, zaś Beata Garlej na przykładzie Flauberta ukazuje wyobcowanie pisarza, poszukującego dla tworzenia „zakamarka”, zapewniającego niezbędny dystans wobec otoczenia. Warto w tym miejscu przypomnieć słowa Virginii Woolf, która w swej słynnej książce - namawiając kobiety do pozyskania własnego skromnego dochodu i intymnej, nienaruszalnej przestrzeni tytułowego „własnego pokoju”, zamykanego na klucz - stwierdzała wprost: „zamek 
w drzwiach to prawo, by myśleć we własnym imieniu"3. Przestrzeń swobodnej twórczości wymaga odcięcia od świata zewnętrznego, który na etapie kreacji bywa dramatycznym zakłóceniem - kreacja co najmniej w równym stopniu potrzebuje jednak perspektywy kontaktu, który warunkuje sens jej istnienia. Nic bowiem dobitniej niż narzucone przerwanie wymiany informacji między twórcą a publicznością nie uświadamia, że dzieło w swej istocie jest przede wszystkim komunikatem.

Zgromadzone artykuły omawiają bardzo różne aspekty zjawiska komunikacji w izolacji, także w jej mrocznym wymiarze - począwszy od analizy pamiętnikarskich opisów doświadczenia jeńców wojennych (Marcin Pliszka, Izolacja więzienna jako doświadczenie egzystencjalne w literaturze polskiego baroku. Wybrane przyktady), przez egzystencję emigrantów, naznaczoną wyobcowaniem kulturowym i próbami nawiązywania dialogu listowego z krajem (Małgorzata Chachaj, Oddzielenie i odosobnienie. Listy Józefa Szymanowskiego do Anieli ze Świdziñskich Szymanowskiej; Joanna Hałaczkiewicz o postawie artysty grafika Stanisława Gliwy, londyńskiego wychodźcy czasów tak zwanej Drugiej Wielkiej Emigracji), aż po wyizolowanie całych społeczeństw i kreowanie alternatywnej rzeczywistości przez propagandzistów, o czym pisze Marek Pąkciński, ukazując Maskowanie klęski w niemieckiej polskojęzycznej prasie gadzinowej w latach 1943-I944 (na przyktadzie tekstów z „Nowego Kuriera Warszawskiego").

Kontekst pandemii pojawia się kilkakrotnie (chociażby w artykule Weroniki Koceli, poświęconym antologiom wierszy o tematyce medycznej), ale nie jest dominantą tomu - wskazuje jedną z najbardziej oczywistych form przymusowej izolacji, która wywiera bezdyskusyjny wpływ na relacje międzyludzkie i ich postrzeganie, jedynie wydobywając na jaw to, co w codziennym życiu często ukryte lub pomijane (na przykład tekst Ewy Szkudlarek Izolacja w firmie). Bardziej związany z konkretnymi okolicznościami charakter prezentacji funkcjonowania wybranych instytucji kultury (Muzeum Narodowe w Warszawie i Zachęta) wobec kwarantanny covidowej ma artykuł Kingi Kamińskiej, praca, która może stać się wstępem do dalszych analiz działań twórców i animatorów kultury, poszukujących nowych dróg kontaktu z odbiorcami w czasach zarazy i wymuszonych przez nią ograniczeń.

Bezpośrednie biologiczne zagrożenie w tym kontekście staje się mniej istotne niż psychiczne skutki odseparowania jednostki od społeczności. Wygnanie poza daną grupę społeczną to kara stosowana nawet w społecznościach będących zgromadzeniami wyrzutków, jak słynne pirackie „marunowanie” (ang. marooning oznacza porzucenie buntowniczego członka załogi na bezludnej wyspie z bronią, niewielkim zapasem żywności oraz prochu i kul). W realiach historycznych wygnanie 
owo miało wymiar skazania na śmierć fizyczną, ale również, a może przede wszystkim, symboliczną. Wyrzucenie poza nawias znanego świata, odcięcie od grupy niesie ze sobą groźbę szaleństwa i dezintegracji osobowości. Dlatego też historia szkockiego marynarza Alexandra Selkirka, który przetrwał ponad cztery lata na wyspie Más a Tierra w archipelagu Juan Fernández u wybrzeży Chile ${ }^{4}$, tak poruszyła powszechną wyobraźnię i legła u podstaw jednej z wielkich powieści Przypadków Robinsona Crusoe, mówiącej o odtwarzaniu porządku świata dzięki sile ducha izolowanej jednostki.

Naturalną ludzką potrzebę komunikacji, szczególnie ostro uświadamianą w warunkach pandemicznego izolowania, potwierdza niezwykły spontaniczny eksperyment rosyjskich użytkowników Facebooka. Założona 30 marca 2020 roku otwarta grupa Izoizolyacia, łącząca ludzi „o ograniczonych możliwościach przemieszczania się i nieograniczonej fantazji” " która zachęca do tworzenia własnych wersji słynnych dzieł kultury (przez ich wierne kopiowanie, pastisz lub parodię), przy jedynych zastrzeżeniach - używania wyłącznie elementów dostępnych w czasie domowej kwarantanny i rezygnacji z graficznych upiększeń typu Photoshop, w ciągu zaledwie miesiąca zyskała ponad pół miliona użytkowników na różnych kontynentach. Wspólnota kulturowych nawiązań, estetycznej wrażliwości i poczucia humoru pozwoliła przebywającym na kwarantannie użytkownikom Facebooka na rozpoczęcie specyficznego podwójnego dialogu z wielkimi dziełami kultury, a jednocześnie ze

4 Wysadzony na brzeg Selkirk został całkiem hojnie wyposażony w użytkowe i symboliczne artefakty kultury, „miał ze sobą swe ubrania i posłanie, krzesiwo, trochę prochu, kule, tytoń, topór, nóż, kociołek, Biblię, trochę praktycznych przedmiotów oraz swe instrumenty i książki matematyczne”. Przedmioty te umożliwiły mu nie tylko przetrwanie fizyczne, ale także zachowanie równowagi psychicznej, pokonanie melancholii i lęku dzięki modlitwom, lekturom i śpiewaniu psalmów, „tak więc oświadczył, iż był lepszym chrześcijaninem, przebywając w swej samotni, niż kiedykolwiek przedtem". (Fragmenty z książki A Cruising Voyage Round the World kapitana Woodesa Rogersa, który uratował Selkirka z jego wyspy w 1709 r., cyt. za: D. Cordingly, Życie $i$ zwyczaje piratów, tłum. M. Utkin, Warszawa 2006, s. 177).

5 Artykuły o przekraczającym granice za pośrednictwem internetu fenomenie Izoizolyacii powstawały już wiosną 2020 r., np. Charles Maynes pisał: „Called «Izoizolyacia» - roughly meaning «Art Isolation» - the Facebook group says it's for people with «limited movement and unlimited fantasy». It invites members to re-create masterworks but with one important restriction of its own: Use only what you have at home. In little over a month, the community has grown to more than a half-million members. Using household items, food, raided wardrobes and a familiar Russian-inflected sense of irony, members have produced dizzyingly creative remakes of everything from European masterpieces to Soviet agitprop and coronavirus-influenced memes" (Ch. Maynes, Russian Speakers Imitate Art in a Time of Coronavirus Confinement on Facebook, 18 maja 2020 r., https://www.npr.org/ 2020/05/18/854388053/russian-speakers-imitate-art-in-a-time-of-coronavirus-confinement-onfacebook?t=1640042765036 (stan z 21 grudnia 2021 r.). Obecnie w sprzedaży znajduje się drukowana wersja albumu Izoizolyacia, prezentującego najlepsze dokonania internetowych twórców (zob. https:// www.facebook.com/groups/izoizolyacia), a dokument o twórczości grupy, reżyserowany przez Sofię Popolitową i Olega Christolubskiego, został zgłoszony na XV Międzynarodowy Festiwal Filmów Dokumentalnych „Артдокфест-2021” (https://artdoc.media/ru/movie/izoizolyaciya_2021_48/ wpis członkini grupy, Niny Rusanowej z 2 grudnia 2021 r., stan z 21 grudnia 2021 r.). 
współczesnymi odbiorcami-komentatorami, dialogu, który przekracza granice czasu i przestrzeni.

Skromnym wkładem Autorów rozpraw naukowych i prac plastycznych, zgromadzonych w 27 numerze „Napisu”, w rozważania nad komunikacją i izolacją jest podjęcie tego frapującego tematu na gruncie polskim w oświetleniu rozmaitych dyscyplin i metodologii, a także ukazanie na niewielkim przecież materiale jego uniwersalności, a zarazem wieloznaczności i różnorodności. Analizując odmienne aspekty komunikacji w izolacji, teksty te udowadniają, że zamknięta przestrzeń odosobnienia może okazać się dla jednostki wyspą szczęśliwą - jednak tylko pod warunkiem, że będzie to Szekspirowska „wyspa pełna głosów”. 